\title{
Thermal characteristics and fate of heavy metals during thermal treatment of Sedum plumbizincicola, a zinc and cadmium hyperaccumulator
}

\author{
Dao-Xu Zhong ${ }^{a}$, Zhao-Ping Zhong ${ }^{\mathrm{a}}$, Long-Hua $\mathrm{Wu}^{\mathrm{b}}{ }^{\mathrm{b}}$, Hui Xue ${ }^{\mathrm{a}}$, Zu-Wei Song ${ }^{\mathrm{a}}$, Yong-Ming Luo ${ }^{\mathrm{c}}$ \\ a Key Laboratory of Energy Thermal Conversion and Control, Ministry of Education, School of Energy and Environment, Southeast University, Nanjing 210096, Jiangsu, China \\ b Key Laboratory of Soil Environment and Pollution Remediation, Institute of Soil Science, Chinese Academy of Sciences, Nanjing 210008, Jiangsu, China \\ c Key Laboratory of Coastal Zone Environmental Processes, Yantai Institute of Coastal Zone Research, Chinese Academy of Sciences, Yantai 264003, Shandong, China
}

\section{A R T I C L E I N F O}

\section{Article history:}

Received 26 July 2014

Received in revised form 14 November 2014

Accepted 14 November 2014

Available online $\mathrm{xxxx}$

\section{Keywords:}

Hyperaccumulators

Heavy metals

Thermal disposal

Thermodynamic analysis

\begin{abstract}
A B S T R A C T
A horizontal tube furnace was designed to test the disposal of ground hyperaccumulator biomass. X-ray diffraction (XRD), thermodynamic analysis and chemical extraction were used to characterise the heavy metals. The recoveries of $\mathrm{Zn}, \mathrm{Pb}$, and $\mathrm{Cd}$ in bottom ash decreased with increasing incineration temperature but increased in fly ash. The recoveries of $\mathrm{Zn}, \mathrm{Pb}$, and $\mathrm{Cd}$ fluctuated with increasing air flow rate and most of the metals were found in the fly ash. $\mathrm{Cd}, \mathrm{Pb}$, and $\mathrm{Zn}$ occurred during the combustion process in the form of elementary substances and their oxides. During reduction in the thermal process both $\mathrm{Pb}$ and $\mathrm{Cd}$ formed metal complexes such as $\mathrm{Ca}_{0.75} \mathrm{Cd}_{0.25} \mathrm{O}$ and $\mathrm{Pb}_{2} \mathrm{O}_{3.333}$ or their mixtures and more of the bottom ash $\mathrm{Zn}$ under the reducing conditions was present as pure metal, crystalline oxides, sulphides or complex compounds combined with other metals.
\end{abstract}

(c) 2014 Elsevier B.V. All rights reserved.

\section{Introduction}

Phytoextraction using hyper-accumulators is considered to be an efficient and low cost technology to remove heavy metals from contaminated soils [1]. Sedum plumbizincicola (S. plumbizincicola), a zinc and cadmium hyperaccumulator, has considerable capability to extract $\mathrm{Zn}$ and $\mathrm{Cd}$ has been demonstrated to successfully remediate $\mathrm{Zn}$ and $\mathrm{Cd}$ contaminated soils $[2,3]$.

It has been reported $[3,4]$ that S. plumbizincicola can produce large biomass containing several thousands of $\mathrm{mg} \mathrm{Zn} / \mathrm{kg}$ and more than one hundred $\mathrm{mg} \mathrm{Cd} / \mathrm{kg}$ will be produced by plants widely grown at a phytoremediation site in Zhejiang Province, east China. Therefore, the safe and economical disposal of the harvested biomass to avoid secondary environmental pollution is a complex problem. When comparing general disposal methods for the contaminated biomass such as composting, compaction, incineration, ashing, pyrolysis, direct disposal, and liquid extraction, incineration is the preferred and recommended option [5]. Thermal disposal methods (incineration or gasification) are feasible and economically acceptable methods that present two advantages. Firstly they involve more than $90 \%$ reduction in the volume of the waste and secondly they destroy organic compounds (near complete). On the other hand, the metal species contained in the waste are not destroyed during high-temperature incineration, but instead condense to form metallic particles during the cooling of the flue gas. Therefore, thermal methods are applicable for metal recovery in cases where the metals are mainly concentrated in solid residues. Metal extraction and recovery from ashes have already been employed industrially for municipal waste incineration plants [6]. In addition, the behaviour and transportation of heavy metals (HMs) during thermal disposal are complex functions of the incinerator operating conditions (including temperature and gas composition) [7-9], the composition of the hyperaccumulator, and the physico-chemical properties of the metals and their compounds (chlorine, sulphur, or alumino-silicates). This is the purpose of studying the behaviour of heavy metals at different temperatures and oxygen concentrations in the combustion gas. In addition, it is important to understand the ash fractions and how HMs will behave during thermal disposal processing.

Some studies related to phytoextraction biomass have been based on theoretical calculations or incinerator operating conditions. Ljung and Nordin [10] modelled the fate of ash-forming elements and HMs during simulation of combustion of Salix species within the temperature range of 100 to $1600{ }^{\circ} \mathrm{C}$ but Lundholm et al. [11] reported some fundamental differences in input thermodynamic data from various databases leading to differences in equilibrium calculations from study to study. Wu et al. [17] investigated the control of HM emissions from incineration and found that kaolin and activated carbon removed most of the $\mathrm{Cd}$ from the flow gas. Yan et al. [12] investigated the volatilization behaviour of arsenic (As) and its mechanism during incineration of Pteris vittata. Lu et al. [13] reported that incineration favours the volatilization of $\mathrm{Cd}$ in contrast to pyrolysis and the contents of HMs in ashes and flow gas were studied in S. plumbizincicola. Lind et al. [14] combusted forest residues and found that heavy metal behaviour in reducing and oxidizing atmospheres was generally different.

In the case of hyper-accumulators, most of the incineration tests have focused on the transport of HMs during thermal treatment or reduced HM concentrations not exceeding the emission standards. The 
Table 1

Proximate and ultimate analysis (wt.\%) of S. plumbizincicola.

\begin{tabular}{|c|c|c|c|c|c|c|c|c|}
\hline \multicolumn{3}{|c|}{ Proximate analysis } & \multicolumn{5}{|c|}{ Ultimate analysis } & \multirow[t]{2}{*}{ Calorific value $(\mathrm{kJ} / \mathrm{g})$} \\
\hline A & VM & $\mathrm{M}$ & C & $\mathrm{H}$ & $\mathrm{N}$ & $\mathrm{S}$ & 0 & \\
\hline 8.17 & 76.33 & 15.5 & 40.2 & 6 & 1.1 & 0.1 & 45.3 & 15.188 \\
\hline
\end{tabular}

Ultimate analysis data and proximate analysis data are expressed on dry (bd) basis. Calorific value is higher calorific value.

interactions between hyper-accumulator composition and the physicochemical properties of the metals and their compounds (chlorine, sulphur, or alumino-silicates) greatly affect the bottom ash metal distribution [15-17]. Further tests on the behaviour of heavy metals during Sedum plant incineration are therefore needed to reveal the transformation of toxic elements and then the mechanisms for methods on reducing their emissions.

The objectives of the present study were to experimentally quantify the impact of temperature, air excess ratio and compounds (chlorine, sulphur, or alumino-silicates) in S. plumbizincicola on the partitioning of heavy metals under simulated incineration conditions and to understand their speciation using thermodynamic calculations. The partitioning of HMs under different incineration conditions was predicted thermodynamically in a well-defined system whose composition corresponded to that during the incineration of hyper-accumulators. The equilibrium calculations focused on the influence of the operating temperature, air excess ratio and compounds (chlorine, sulphur, or alumino-silicates) in the combustion residues and flow gas on heavy metal speciation. The thermodynamic calculations focused on the influence of operating temperatures in the range of $350-1950{ }^{\circ} \mathrm{C}$ and the oxygen contents in the combustion gas. The theoretical thermodynamic results were then compared with several analytical results (XRD and sequential chemical extraction) related either to the HM distribution among bottom ash, fly ash and flue gas from different temperatures and air flow rates or to the chemical species in the samples from tubular furnace reactor experiments. The study focused on $\mathrm{Zn}, \mathrm{Cd}$, and $\mathrm{Pb}$ but the behaviour of other compounds found in S. plumbizincicola such as $\mathrm{S}, \mathrm{Al}, \mathrm{Ca}, \mathrm{Si}$, and $\mathrm{Cl}$ was also briefly studied.

\section{Materials and methods}

\subsection{Materials}

S. plumbizincicola biomass was collected from the location where it was originally found at a $\mathrm{Pb} / \mathrm{Zn}$ mine area in Chun'an City, Zhejiang Province, east China. The biomass for combustion tests was dried at $85^{\circ} \mathrm{C}$ in an oven for $8 \mathrm{~h}$ before testing in a horizontal quartz tube. The proximate and ultimate analysis of S. plumbizincicola is shown in

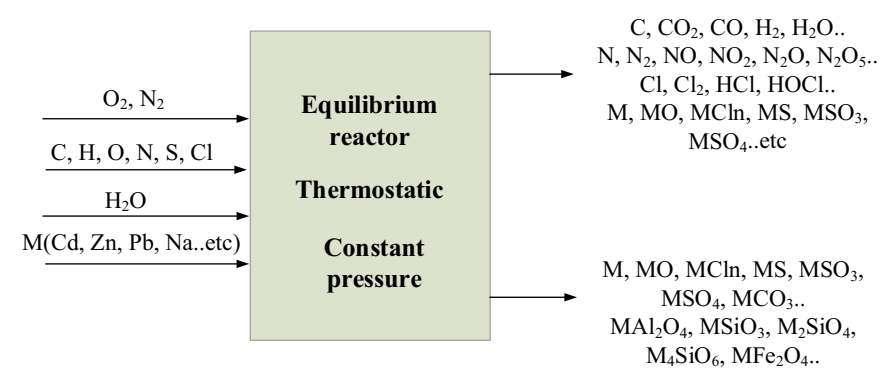

Fig. 2. Thermodynamic equilibrium calculations of incineration (M: elements of S. plumbizincicola).

Table 1. The elemental compositions $(\mathrm{mg} / \mathrm{kg}$ ) of $\mathrm{S}$. plumbizincicola were $9838 \pm 289(\mathrm{Zn}), 560 \pm 6(\mathrm{Cd}), 62.5 \pm 3.7(\mathrm{~Pb}), 77.6 \pm 1.7$ (Cu), $45.4 \pm 6.0(\mathrm{Cr}), 642 \pm 46(\mathrm{Fe}), 84.8 \pm 6.9(\mathrm{Na}), 13976 \pm 543$ $(\mathrm{Al}), 61886 \pm 805(\mathrm{Ca})$, and $1135 \pm 15(\mathrm{Cl})$, respectively; and the $\mathrm{SiO}_{2}$ content was $850 \mathrm{mg} / \mathrm{kg}$.

\subsection{Experimental facility}

The experimental facility, shown in Fig. 1, contained two high pressure gas sources $\left(\mathrm{O}_{2}, \mathrm{~N}_{2}\right)$, a flow control valve and meter, a horizontal quartz tube with a surrounding electrically heated furnace, and a flue gas absorption device. The horizontal quartz tube had an inner diameter of $45 \mathrm{~mm}$ and a length of $1000 \mathrm{~mm}$, of which $400 \mathrm{~mm}$ was in the temperature controlled reaction zone heated and controlled by the electrical furnace from 100 to $1100^{\circ} \mathrm{C}$. All flue gas samples were collected in each experiment. The absorption device was based on US EPA Method 29. The joint between the quartz tube and the absorption bottle was plugged with glass fibre filter material to sample the fly ash. The experiments were performed at temperatures from 350 to $950{ }^{\circ} \mathrm{C}$ and air flow rates of $0.5,0.75,1.0$, and $1.2 \mathrm{~L} / \mathrm{min}$. About $3 \mathrm{~g}$ of S. plumbizincicola powder was placed in a dried and weighed quartz weighing boat and transferred into the centre of the quartz tube which was pre-heated to the desired temperature. The gas flow was introduced into the quartz tube before the start of the experiments. After each experiment the absorption bottles containing $5 \% \mathrm{HNO}_{3}+10 \% \mathrm{H}_{2} \mathrm{O}_{2}$ solution were removed and replaced by another set of bottles to dispose of the exhaust gas. Bottom ash and fly ash were carefully taken out, allowed to cool to room temperature, weighed, and sealed in a sampling bag.

\subsection{Determination of heavy metals}

Solid samples of fly ash and bottom ash were digested with a solution of $\mathrm{HNO}_{3}, \mathrm{HClO}_{4}$ and $\mathrm{HF}\left(3: 2: 1 \mathrm{HNO}_{3}: \mathrm{HClO}_{4}\right.$ : $\mathrm{HF}$ by volume) for

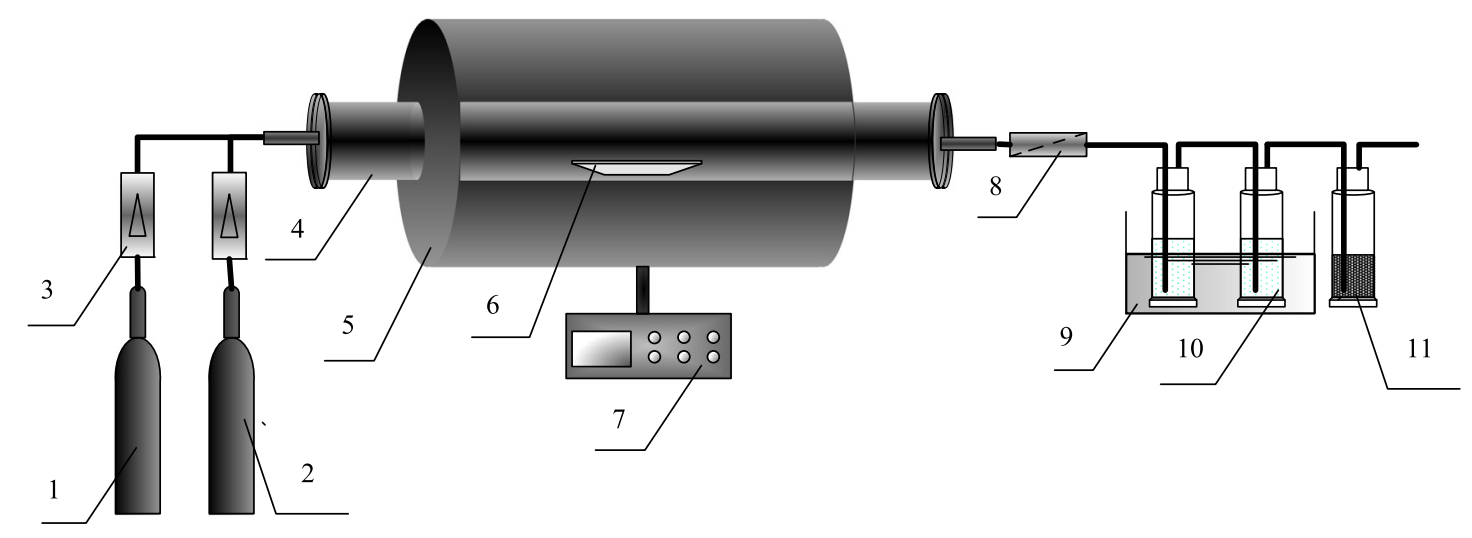

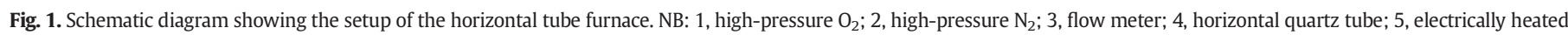
furnace; 6, quartz boat; 7, temperature controller; 8 , fibreglass filter 9, iced-water bath; 10 , absorption solution $1\left(5 \% \mathrm{HNO}_{3}+10 \% \mathrm{H}_{2} \mathrm{O}_{2}\right) ; 11$, silica gel. 


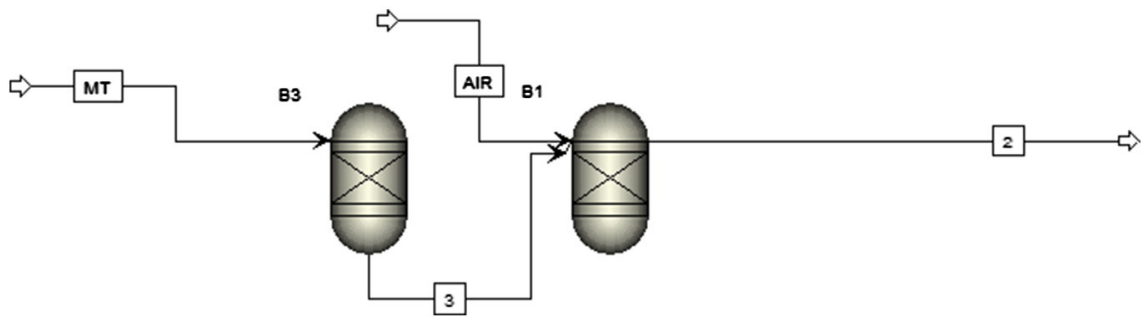

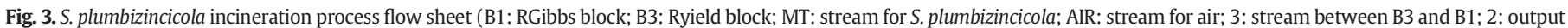
stream).

determination of $\mathrm{Cd}, \mathrm{Zn}$, and $\mathrm{Pb}$. Then the $\mathrm{Zn}$ and $\mathrm{Pb}$ concentrations were determined by flame atomic absorption spectrophotometry (Varian SpectrAA 220FS). The solution Cd concentration was determined with a Varian SpectrAA $220 Z$ spectrophotometer using a graphite furnace.

\subsection{Equipment and method for TG-DTG experiment}

A TG-DTG (SetaramSetsys evolution 16) analyser was used to study the evolution of weight and volatile matter of S. plumbizincicola biomass during pyrolysis and combustion. Approximately $20 \mathrm{mg}$ of the sample was used for pyrolysis and $10 \mathrm{mg}$ for combustion in this study. It was crushed to a powder finer than $0.2 \mathrm{~mm}$. Room temperature to $800{ }^{\circ} \mathrm{C}$ was set as the temperature range and the heating rate was set at $10{ }^{\circ} \mathrm{C} / \mathrm{min}$. Nitrogen was used as the inert gas during pyrolysis and air was used during combustion.

\subsection{Thermodynamic simulation by advanced system for process engineering (ASPEN)}

Combustion of S. plumbizincicola constitutes a multi-component and multi-phase system. To identify the dominant species of each element the principle of minimising the total Gibbs free energy of the system was used to calculate the thermodynamic equilibrium. The final equilibrium state is obtained by determining all possible species that can be derived from the elements of the input system. The analysis serves to determine the major metallic species and to predict the possible chemical interactions between the HM and the matrix components (Fig. 2).

The process flow-sheet consists of two blocks (Ryield and Rgibbs) and four streams (Fig. 3). Material stream (MT stream) pyrolysis in the Ryield block and then incineration in the RGibbs block. The flow rate of the material stream was set at $20 \mathrm{~kg} / \mathrm{h}$ and the air excess ratio set at 1.2 .

\subsection{Chemical extraction series}

The operating conditions of each step are described in Table 2. Steps 3 and 4 determined the "easily reducible" and the "moderately reducible" phases, respectively, as defined by Kersten and Förstner [15]. A boric acid attack to dissolve possible fluoride precipitates and to eliminate the HF excess supplemented the last extraction step. To respect fixed $\mathrm{pH}$ procedures, $\mathrm{HNO}_{3}$ was added during steps 1 and 2 to maintain the $\mathrm{pH}$ of the solution. The solid to extractant ratio was $1 \mathrm{~g} 10 \mathrm{ml}^{-1}$ for all steps.

\section{Results and discussion}

\subsection{TG-DTG studies on S. plumbizincicola}

As displayed in Fig. 4, the pyrolysis process of the sample can be divided into three steps. At the first step, moisture evaporated when the temperature was less than $170{ }^{\circ} \mathrm{C}$, about $9.51 \%$ of the S. plumbizincicola biomass. The second step, the fast decomposition stage, was from 170 to $400{ }^{\circ} \mathrm{C}$. Hemicelluloses and cellulose cracks in this state were lost, peaked at $306{ }^{\circ} \mathrm{C}$, and about $50.8 \%$ of the weight of S. plumbizincicola was lost during this stage. At the third step further cracking of fixed carbon occurred and the temperature was from $400{ }^{\circ} \mathrm{C}$ to the end point of the experiment. The weight loss of the sample during the whole pyrolysis process of S. plumbizincicola was $73.9 \%$. Similar to pyrolysis, the combustion process of the sample can also be divided into three stages. The first step was from room temperature to $185^{\circ} \mathrm{C}$, with about $6.17 \%$ biomass weight of S. plumbizincicola lost. The second step was from $185{ }^{\circ} \mathrm{C}$ to $400{ }^{\circ} \mathrm{C}$, the fast decomposition stage and similar to the pyrolysis process. About $50.4 \%$ of weight of S. plumbizincicola was lost during this stage. Before $400{ }^{\circ} \mathrm{C}$, the pyrolysis and combustion processes had similar DTG curves, indicating that the presence of oxygen did not accelerate the weight loss of the sample at low temperature. At the third step combustion of fixed carbon occurred from 400 to $697^{\circ} \mathrm{C}$. It was observed that the weight loss during combustion was even greater than that during pyrolysis during this stage so that oxidation of inorganic constituents of the sample might have occurred during combustion. The total weight loss of S. plumbizincicola during the combustion process was $89.4 \%$.

Both pyrolysis and combustion of S. plumbizincicola were divided into three steps. The weight loss performance of S. plumbizincicola was similar in both pyrolysis and combustion conditions at low temperatures, indicating that the presence of oxygen did not accelerate the weight loss of the sample at low temperatures. It was observed that the weight loss during combustion was even greater than that during pyrolysis in the third step, which indicates that oxidation of inorganic ingredients of the sample might occur during combustion. The TG curve of combustion of S. plumbizincicola was similar to that of other energy crops, wood or municipal solid wastes [18-21] and appropriate biomass characteristics, low input demand and positive environmental impact. S. plumbizincicola is thus a potential renewable energy source and a substitute for the declining supply of fossil fuel resources.

Table 2

Procedure of chemical extraction series.

\begin{tabular}{|c|c|c|}
\hline Step & Reagent & Condition \\
\hline Water soluble & De-ionised water (DW) & $20^{\circ} \mathrm{C}, 3 \mathrm{~h}, \mathrm{pH} 7$, continuous agitation \\
\hline Acid soluble & $0.5 \mathrm{M} \mathrm{CH}_{3} \mathrm{COOH}+0.1 \mathrm{M} \mathrm{Ca}\left(\mathrm{NO}_{3}\right)_{2}$ & $20{ }^{\circ} \mathrm{C}, 3 \mathrm{~h}, \mathrm{pH} 5$, continuous agitation \\
\hline Easily reducible & $0.175 \mathrm{M}\left(\mathrm{NH}_{4}\right)_{2} \mathrm{C}_{2} \mathrm{O}_{4}+0.1 \mathrm{M} \mathrm{H}_{2} \mathrm{C}_{2} \mathrm{O}_{4}$ & $95^{\circ} \mathrm{C}, 3 \mathrm{~h}$, variable agitation, without light \\
\hline Moderately reducible & $0.1 \mathrm{M} \mathrm{Na}_{2}$ EDTA $+0.3 \mathrm{M} \mathrm{NH}_{2} \mathrm{OH} \cdot \mathrm{HCl}$ & $95^{\circ} \mathrm{C}, 24 \mathrm{~h}$, variable agitation \\
\hline Residual & $10 \mathrm{~mL} \mathrm{HCl} 36 \%+5 \mathrm{~mL} \mathrm{HNO}_{3} 69 \%+2.5 \mathrm{~mL} \mathrm{HF} 40 \%+2.5 \mathrm{~mL} \mathrm{DW}$ & $150{ }^{\circ} \mathrm{C}, 48-72 \mathrm{~h}$, continuous agitation \\
\hline
\end{tabular}




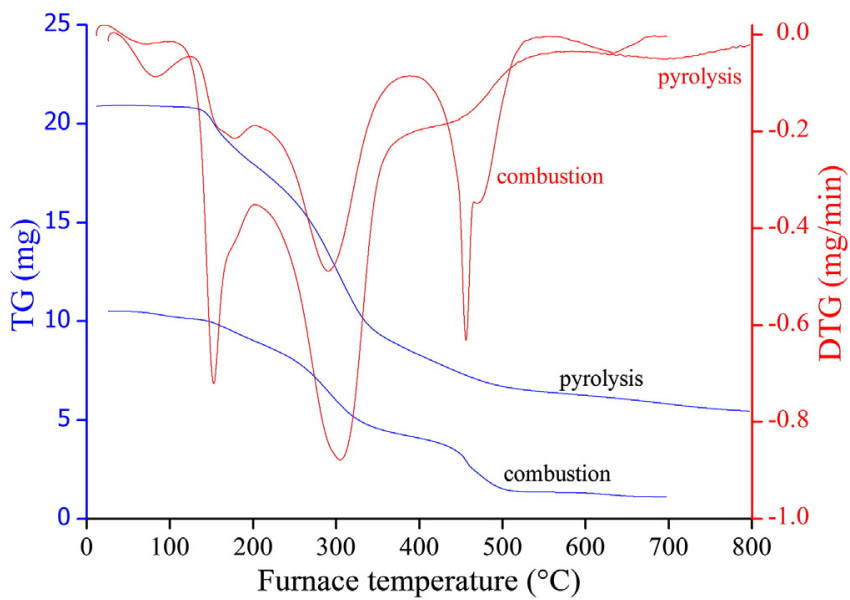

Fig. 4. TG/DTG of S. plumbizincicola.

\subsection{Effect of temperature on plant heavy metal behaviour}

Temperature has a significant impact on the HM volatilization process. The higher the temperature the higher the HM vaporization rate, although the vaporization rate is not linearly proportional to the incineration temperature [22,23]. The recovery of heavy metals is depicted in Fig. 5. The most volatile metal during S. plumbizincicola biomass combustion was Cd. Almost $80.0 \%$ of Cd was present in the fly ash and only less than $0.01 \%$ occurred in the flow gas. Cd vaporized at temperatures above $380{ }^{\circ} \mathrm{C}$ and significant $\mathrm{Cd}$ species condensation occurred at temperatures lower than $380{ }^{\circ} \mathrm{C}$ and captured by the fly ash $[24,25]$. At temperatures of $350-650^{\circ} \mathrm{C}$ the major portion of $\mathrm{Pb}(>95 \%)$ and $\mathrm{Zn}$ $(>90 \%)$ remained in the bottom ash. Only a minority of lead (almost $3 \%$ ) and about $10 \%$ of $\mathrm{Zn}$ were found in the fly ash and were not detectable in the flow gas. The recoveries of $\mathrm{Pb}$ and $\mathrm{Zn}$ decreased with increasing temperature when $\mathrm{T}>650^{\circ} \mathrm{C}$. Therefore, it can be concluded that $\mathrm{Pb}$ and $\mathrm{Zn}$ were largely volatilized at reactor temperatures above $650{ }^{\circ} \mathrm{C}$ and condensation occurred at temperatures below $650{ }^{\circ} \mathrm{C}$. Thus, most of the $\mathrm{Pb}$ and $\mathrm{Zn}$ were found in the fly ash when the temperature was above $650{ }^{\circ} \mathrm{C}$. $\mathrm{Cd}$ and $\mathrm{Pb}$ are considered to be more harmful than $\mathrm{Zn}$ and the less volatile metals $(\mathrm{Zn}$ and $\mathrm{Pb})$ are retained in the bottom ash under low temperatures $\left(<650{ }^{\circ} \mathrm{C}\right)$. Cadmium is more volatile and is concentrated in the fly ash $(>80 \%)$. The higher the temperature, the higher the HM vaporization rate and more of the metals concentrate in the fly ash, which generally follows the volatilization behaviour of HMs during incineration. HMs initially vaporize in the flame and the resultant metallic vapours then undergo homogeneous nucleation

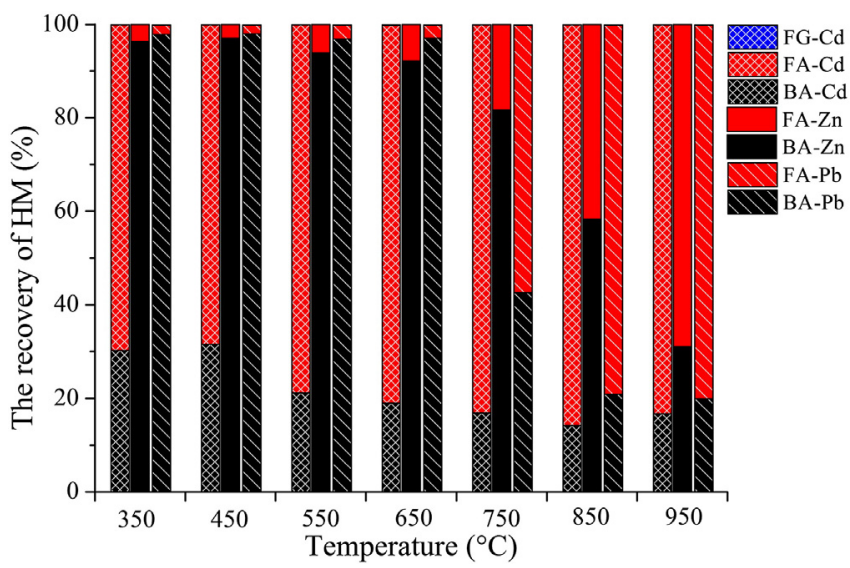

Fig. 5. Impact of temperature on transport of recovery of HMs during incineration of S. plumbizincicola (FA represents fly ash, and BA represents bottom ash). to form an ultrafine aerosol [26,27]. In the post-incineration region the flue gas cools rapidly and the condensed aerosol of HMs and their oxides increases continuously by heterogeneous coagulation in the fly ash so that less of the HM was found in the flow gas [25].

$\mathrm{HM}$ volatility was sensitive to chlorine and sulphur contents, $\mathrm{S} / \mathrm{Cl}$ ratio, and the content of alkali metals $[28,29]$. Fig. 6 shows that heavy metal volatile compounds occurred preferentially with $\mathrm{Cl}$ as $\mathrm{CaCl}_{2}$ and $\mathrm{KCl}$ because the ratio of $(\mathrm{S}+\mathrm{Cl}) /($ alkali metals) was about $0.02(\mathrm{w} / \mathrm{w})$ in our experiments, i.e. the alkali metals were in strong abundance and they tended to react with $\mathrm{Cl}$ to form $\mathrm{CaCl}_{2}$ and $\mathrm{KCl}$, suggesting a stronger influence on decreasing the volatility of the HMs. Sulphur, iron, aluminium, and silicates have been reported to be important compounds in the vapour of heavy metals [26,30]. Fig. $6 \mathrm{~b}$ shows that most of the $\mathrm{S}, \mathrm{Fe}, \mathrm{Al}$, and $\mathrm{SiO}_{2}$ were found as $\mathrm{SO}_{2}, \mathrm{Fe}_{2}\left(\mathrm{SO}_{4}\right)_{3}, \mathrm{Fe}_{2} \mathrm{O}_{3}, \mathrm{FeO}, \mathrm{Ca}_{3} \mathrm{Al}_{2} \mathrm{O}_{6}$, $\mathrm{K}_{2} \mathrm{SiO}_{3}$, and $\mathrm{SiO}_{2}$ during the combustion process instead of reacting with HMs. Therefore, the partitioning of HMs during the combustion process varies significantly with the element type. Fig. 6a shows the equilibrium distributions of different HMs in the temperature range of $350-1950{ }^{\circ} \mathrm{C}$ for a typical air excess ratio $\mathrm{a}=1.2$. $\mathrm{Zn}$ was found as $\mathrm{Zn}, \mathrm{ZnO}, \mathrm{Zn}_{2} \mathrm{SiO}_{4}, \mathrm{ZnSiO}_{3}$, and $\mathrm{ZnCO}_{3}$. When the temperature was $>650{ }^{\circ} \mathrm{C}, \mathrm{Zn}, \mathrm{Zn}_{2} \mathrm{SiO}_{4}, \mathrm{ZnSiO}_{3}$, and $\mathrm{ZnCO}_{3}$ decreased and $\mathrm{ZnO}$ increased with increasing temperature. $\mathrm{Cd}$ was found mainly as $\mathrm{Cd}$ and CdO. At low temperatures $\left(<750{ }^{\circ} \mathrm{C}\right) \mathrm{CdSiO}_{3}$ was found and decreased with increasing temperature. $\mathrm{Pb}$ was the major species at low temperatures $\left(<750{ }^{\circ} \mathrm{C}\right)$; at higher temperatures $\mathrm{PbO}$ was the dominant species. Because of the low concentration of $\mathrm{Cl}(1135 \pm 15 \mathrm{mg} / \mathrm{kg})$ in S. plumbizincicola, easily volatilized $\mathrm{CdCl}_{2}$ and $\mathrm{PbCl}_{2}$ were not found. Thus, most of the $\mathrm{Zn}, \mathrm{Cd}$ and $\mathrm{Pb}$ were present as pure metals and their oxides. The powdered XRD patterns of fly ash and bottom ash are
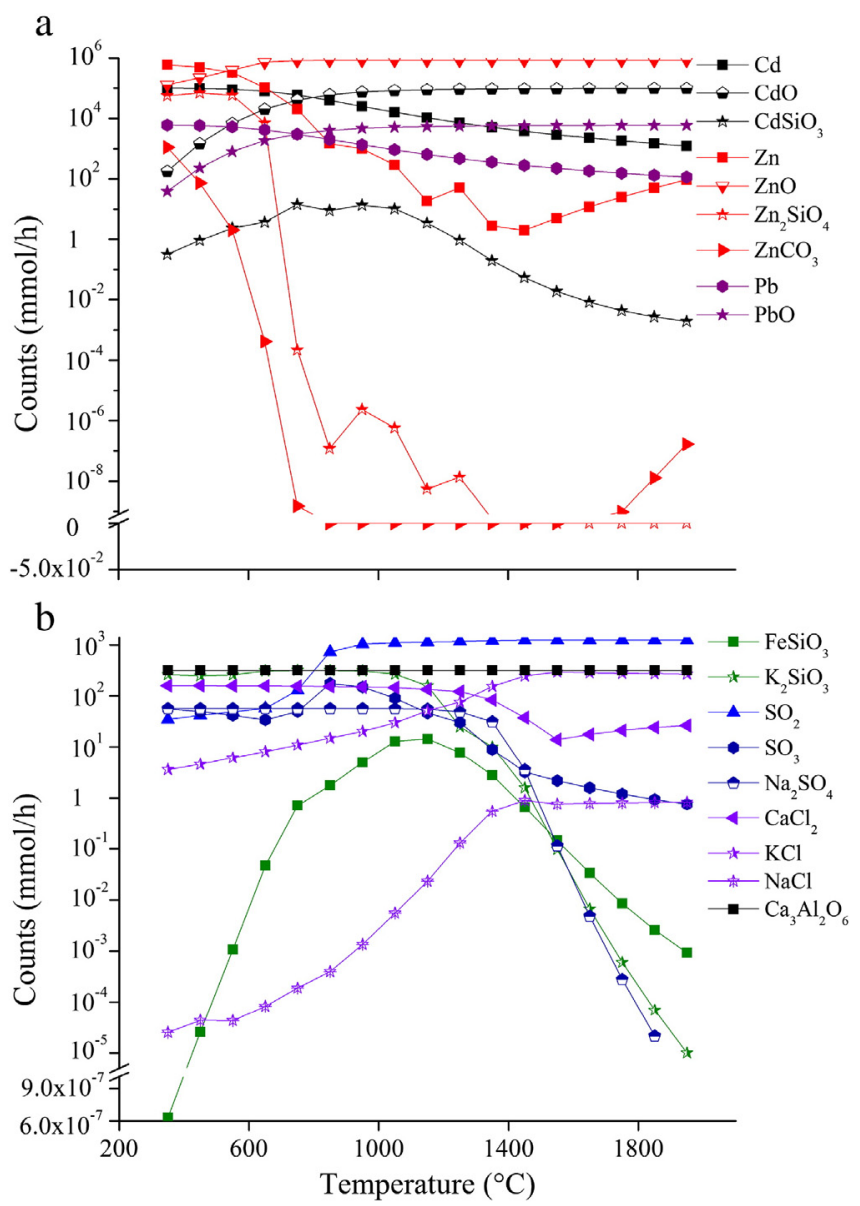

Fig. 6. Equilibrium distribution of HMs versus temperature of S. plumbizincicola simulated by Aspen. 
shown in Fig. 7. In combustion conditions crystalline phases of $\mathrm{Zn}$ in the bottom ash at $850{ }^{\circ} \mathrm{C}$ were found as $\mathrm{ZnO}$ and $\mathrm{Zn}(\mathrm{OH})_{2}$, and $\mathrm{Zn}$, $\mathrm{Zn}_{2} \mathrm{Cu}\left(\mathrm{AsO}_{4}\right)_{2}$, and $\mathrm{Zn}_{2} \mathrm{Cu}\left(\mathrm{AsO}_{4}\right)_{2}$ were found in the fly ash. Crystalline phases of $\mathrm{Cd}$ in the bottom ash were found as $\mathrm{CdO}$ and $\mathrm{CaO}_{0.67} \mathrm{Cd}_{0.33} \mathrm{CO}_{3}$ in bottom ash and $\mathrm{Cd}$ in the fly ash. At $650{ }^{\circ} \mathrm{C}$ alumino-ZnO and ferric oxide- $\mathrm{Pb}$ were found but crystalline phases of $\mathrm{Cd}$ were not found. The results of the sequential chemical extraction (Fig. 8) show that $\mathrm{Cd}, \mathrm{Zn}$, and $\mathrm{Pb}$ had weak mobility and were mainly in the 'acid soluble', 'moderately reducible' and 'residual', fractions so that the metals were associated with carbonates, silicates, alumino-silicates, crystalline pure metals or as crystalline oxides [30].

The mineral matter content of waste affects the heavy metal partitioning through the formation of binary or ternary oxides that can greatly decrease the volatilization of metals [31,32]. The presence of $\mathrm{SiO}_{2}$ and $\mathrm{Al}_{2} \mathrm{O}_{3}$ can lead to the formation of stable $\mathrm{HM}$ salts (silicates and meta-aluminates) and function as sorbents [5]. However, in the present study the alkali present tended to react with $\mathrm{SiO}_{2}$ and $\mathrm{Al}_{2} \mathrm{O}_{3}$ to form alkali salts instead of HM salts.

\subsection{Impact of air flow rate on behaviour of heavy metals}

The air flow rate is an important parameter controlling the combustion process [33]. The conventional mass burn systems require $20-100 \%$ excess air over the stoichiometric value [34], resulting in an oxidizing atmosphere in a typical incinerator. Nevertheless, reducing conditions may exist around and inside combusting particles in the combustion zone even if the air supply is above the theoretical value. The influence of the total air flow rate (characterised by the air excess ratio) was studied at $850{ }^{\circ} \mathrm{C}$ and both reducing and oxidizing conditions were considered by varying air flow rate between 0.5 and $1.2 \mathrm{~L} / \mathrm{min}$. The results for $\mathrm{Zn}, \mathrm{Cd}$, and $\mathrm{Pb}$ are displayed in Fig. 9. For $\mathrm{Cd}$ and $\mathrm{Pb}$ the recovery rates from fly ash are higher than from bottom ash. The recoveries of $\mathrm{Zn}, \mathrm{Pb}$, and $\mathrm{Cd}$ fluctuated with increasing air flow rate. More $\mathrm{Pb}$ and $\mathrm{Cd}$ were found in the bottom ash under the reduced conditions (air flow rate $<0.75 \mathrm{~L} / \mathrm{min}$ ) than the oxidized conditions, while more $\mathrm{Zn}$ was found in the bottom ash during the oxidized conditions.

Fig. 10 shows the equilibrium distributions of different HMs in an air excess ratio range of $0.2-2$ for a typical temperature of $850{ }^{\circ} \mathrm{C}$. $\mathrm{Zn}$ is alternatively found as $\mathrm{Zn}, \mathrm{ZnO}$, and $\mathrm{ZnS}$ when a $<0.6$, and only $\mathrm{ZnO}$ was found when $\mathrm{a}>0.6 \mathrm{Cd}$ and $\mathrm{CdS}$ were found in reducing conditions $(\mathrm{a}<1)$, while $\mathrm{CdO}$ and $\mathrm{Cd}$ were found when $\mathrm{a}>0.2 . \mathrm{Pb}$ and $\mathrm{PbS}$ were the dominant species when $\mathrm{a}<1$ and the mass of $\mathrm{PbO}$ increased with increasing air excess ratio. Concentrations of $\mathrm{Cl}$ in S. plumbizincicola were low, and $\mathrm{PbCl}_{2}$ and $\mathrm{ZnCl}_{2}$ were formed when $\mathrm{a}<0.4$ and $\mathrm{a}<1$, respectively. However, most $\mathrm{Zn}, \mathrm{Cd}$, and $\mathrm{Pb}$ existed as $\mathrm{Zn}, \mathrm{ZnO}, \mathrm{ZnS}, \mathrm{Cd}$, $\mathrm{CdS}, \mathrm{Pb}$, and $\mathrm{PbS}$ in reducing conditions (Fig. 4). From the point of view of environmental protection, combustion would be better as a potential choice for thermal treatment of hyper-accumulators.

In pyrolysis conditions crystalline phases of $\mathrm{Cd}, \mathrm{Zn}$, and $\mathrm{Pb}$ in the bottom ash were found as $\mathrm{Ca}_{0.75} \mathrm{Cd}_{0.25} \mathrm{O}, \mathrm{Pb}_{2} \mathrm{O}_{3.333}$, and $\mathrm{ZnS}$ (Fig. $7 \mathrm{c}$ ). In the fly ash crystalline phases of $\mathrm{Zn}$ were found as $\mathrm{ZnO}, \mathrm{ZnS}$, and organic- $\mathrm{Zn}$, and phases of $\mathrm{Cd}$ and $\mathrm{Pb}$ were found to form complex compounds with other metals ( $\mathrm{Cu}, \mathrm{Al}$, and $\mathrm{Ag}$ ) (Fig. 7e).

The sequential extractions of $\mathrm{Cd}$ and $\mathrm{Pb}$ showed a weak mobility in bottom ash (Fig. 11). In contrast, Zn was mainly in easily leachable phases, indicating that $\mathrm{Zn}$ may be present as the carbonate or as free metal. Moreover, much of the $\mathrm{Pb}$ and $\mathrm{Cd}$ were mainly in the 'moderately reducible' and 'residual' fractions. Also, according to the results of the equilibrium distributions (Fig. 6) and XRD (Fig. 7c and Fig. 7e), the phases of $\mathrm{Cd}, \mathrm{Zn}$, and $\mathrm{Pb}$ could be pure metals, crystalline oxides,

Fig. 7. Powdered XRD patterns of fly ash and bottom ash. X-ray diffraction traces for $2 \theta=$ $13-90^{\circ} \mathrm{Cu} K \alpha$ radiation. Vertical bars in various colours refer to the $2 \theta$ positions of the $\mathrm{X}$ ray reflections for the 8 crystalline phases (A: bottom ash of combustion at $650{ }^{\circ} \mathrm{C}, \mathrm{B}$ : bottom ash of combustion at $850^{\circ} \mathrm{C}, \mathrm{C}$ : bottom ash of pyrolysis at $850{ }^{\circ} \mathrm{C}$, D: fly ash of combustion at $850^{\circ} \mathrm{C}$, E: fly ash of pyrolysis at $850{ }^{\circ} \mathrm{C}$ ).
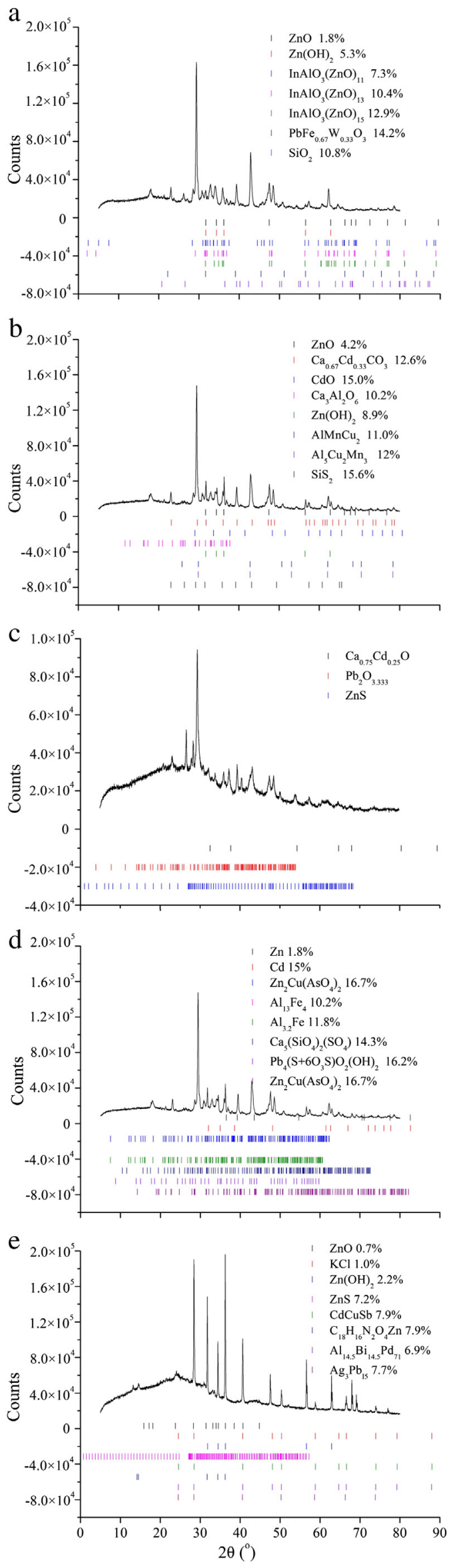


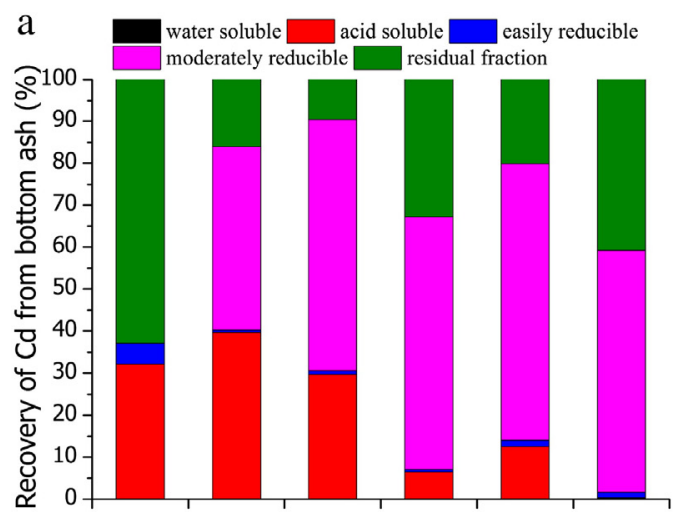

b
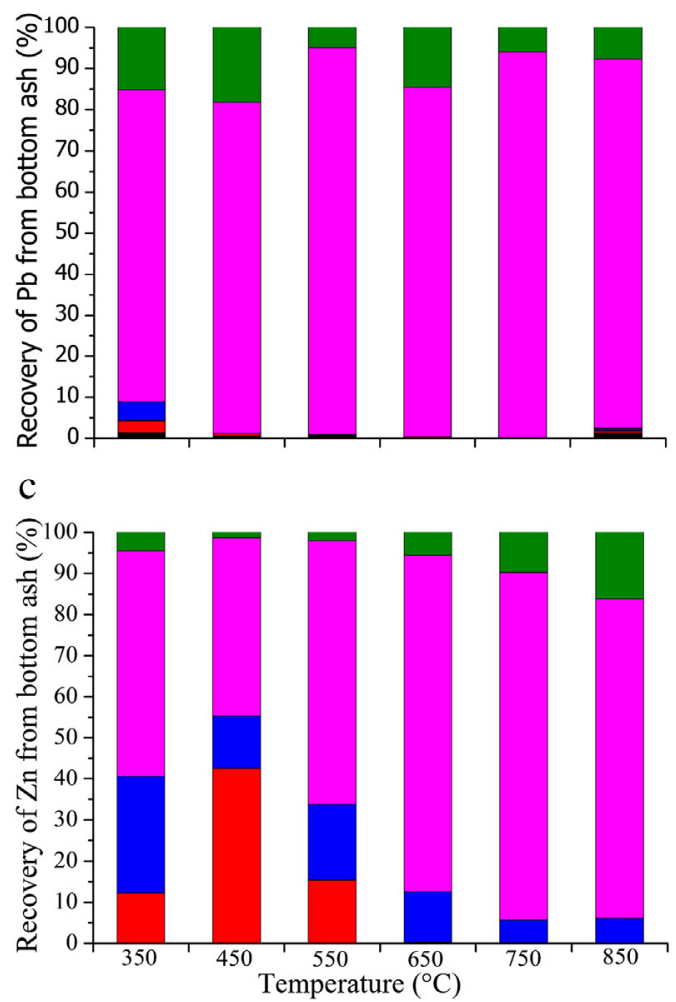

Fig. 8. Results of sequential chemical extraction for $\mathrm{Cd}, \mathrm{Zn}$, and $\mathrm{Pb}$ versus temperature.

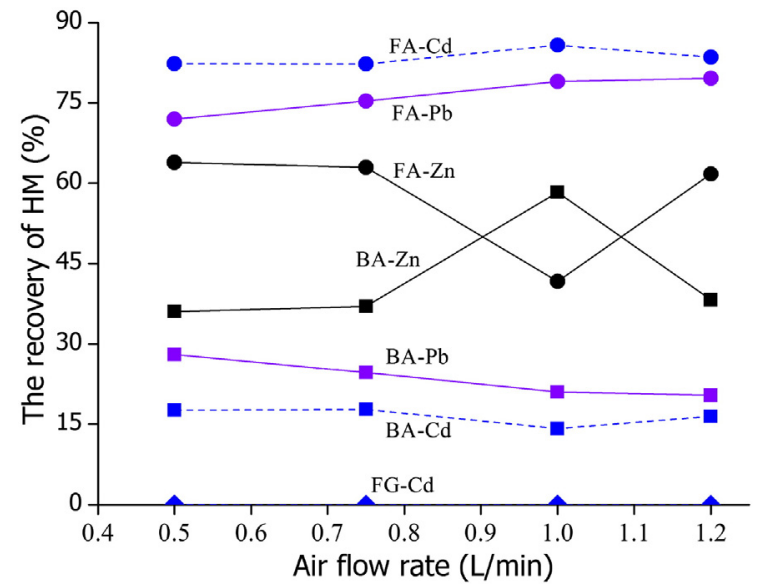

Fig. 9. The impact of air flow rate on transport of recovery of HMs during incineration of S. plumbizincicola.
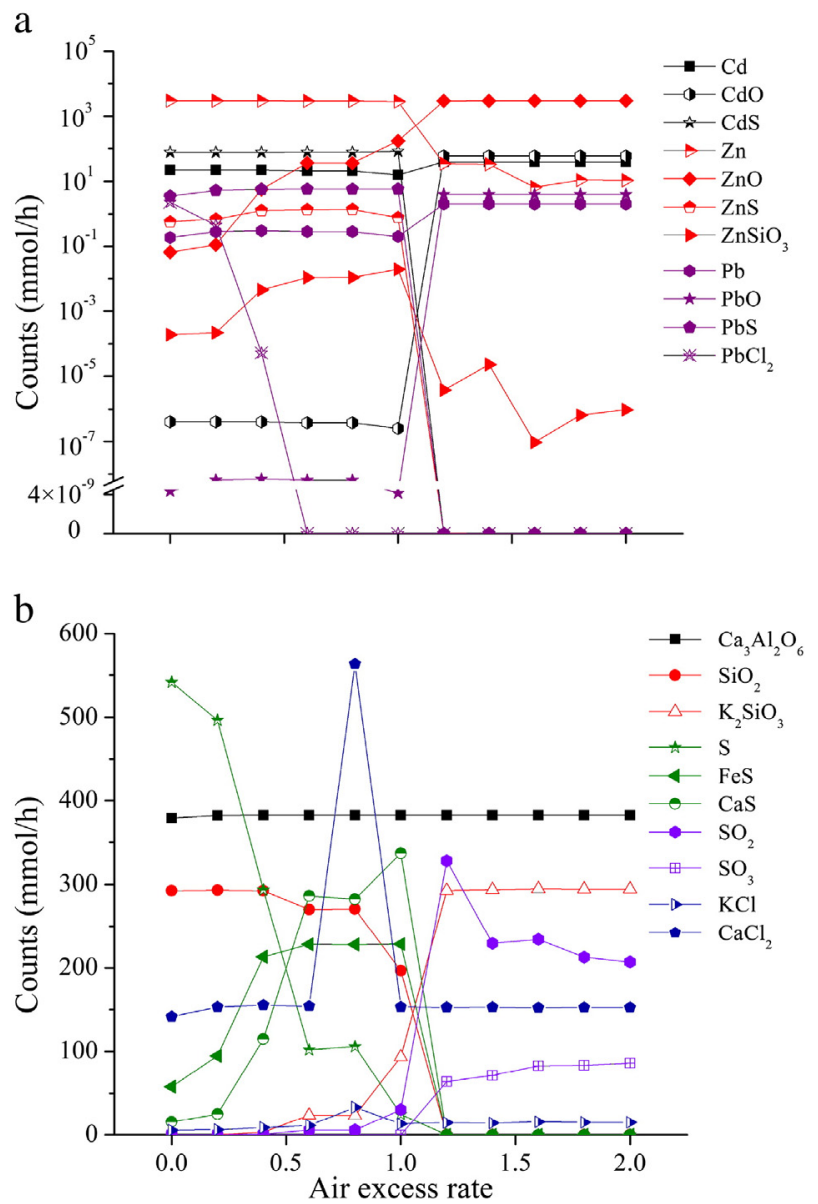

Fig. 10. Equilibrium distribution of HMs versus air excess ratio of S. plumbizincicola simulated by Aspen.

sulphides or more complex compounds. $\mathrm{Cl}, \mathrm{Al}_{2} \mathrm{O}_{3}$, and $\mathrm{SiO}_{2}$ showed little effect on the vapour of HMs during the reductive conditions because they were present mostly as alkali salts. At higher temperatures $\left(>850^{\circ} \mathrm{C}\right.$ ) both the oxidizing atmosphere and reducing conditions favour the transfer of HMs such as $\mathrm{Cd}, \mathrm{Pb}$, and $\mathrm{Zn}$ to the fly ash phase as is observed in municipal solid waste incineration [35]. The recoveries of $\mathrm{Zn}, \mathrm{Pb}$, and $\mathrm{Cd}$ fluctuated with increasing air flow rate. More $\mathrm{Pb}$ and $\mathrm{Cd}$ were found in the bottom ash under reducing conditions (air flow rate $<0.75 \mathrm{~L} / \mathrm{min}$ ) than oxidizing conditions and more $\mathrm{Zn}$ was found in the bottom ash during oxidizing conditions.

Taken together with our previous in vitro data, the results indicate that more $\mathrm{Pb}$ and $\mathrm{Cd}$ were found in the bottom ash under the reducing conditions (air flow rate $<0.75 \mathrm{~L} / \mathrm{min}$ ) than the oxidizing conditions because the $\mathrm{Pb}$ and $\mathrm{Cd}$ form heavy metal complex compounds such as $\mathrm{Ca}_{0.75} \mathrm{Cd}_{0.25} \mathrm{O}, \mathrm{Pb}_{2} \mathrm{O}_{3.333}$ or complex compounds with other metals ( $\mathrm{Cu}$, $\mathrm{Al}$, and $\mathrm{Ag}$ ) which were in the 'moderately reducible fraction' and 'residual fraction' in the sequential extractions of $\mathrm{Cd}$ and $\mathrm{Pb}$. However more $\mathrm{Zn}$ was found in the bottom ash during the oxidizing conditions because $\mathrm{Zn}$ should be in the $\mathrm{Zn}(\mathrm{g})$ form in reducing conditions above $850^{\circ} \mathrm{C}$. Further reactions that have to be considered are the subsequent homogeneous reactions in the gaseous phase. The oxidation of volatile zinc by carbon dioxide to solid zinc oxide and carbon monoxide (reaction 1) and especially the homogeneous oxidation of gaseous zinc by steam to solid zinc oxide and hydrogen (reaction 2) proceed at temperatures above $750{ }^{\circ} \mathrm{C}$ and are described for pyrometallurgic processes $[36,37]$.

$\mathrm{Zn}(\mathrm{g})+\mathrm{CO}_{2}=\mathrm{ZnO}(\mathrm{s})+\mathrm{CO}(\mathrm{g})$ 


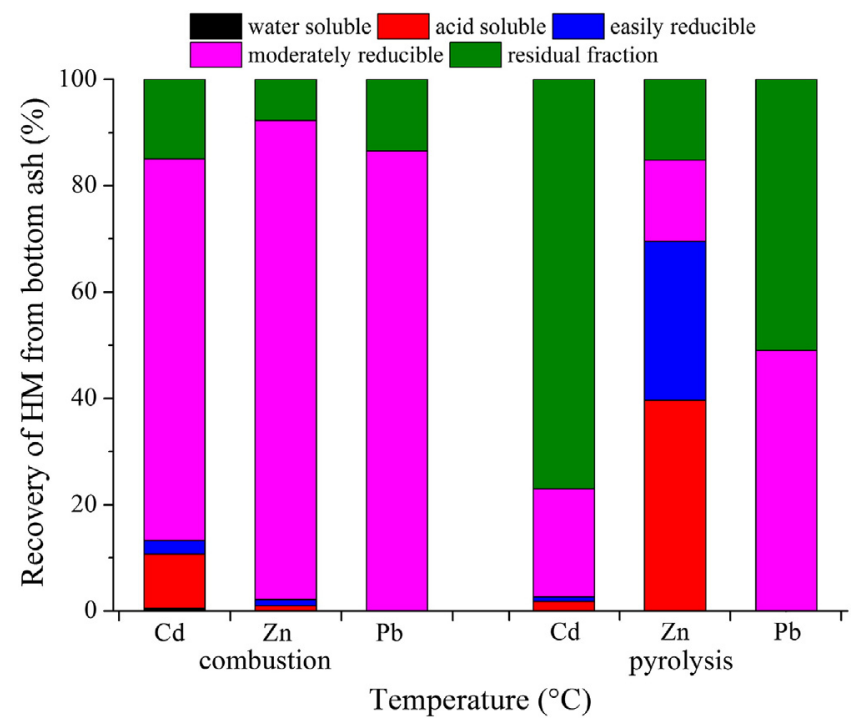

Fig. 11. Sequential chemical extraction for $\mathrm{Cd}, \mathrm{Zn}$, and $\mathrm{Pb}$ versus oxygen content.

$\mathrm{Zn}(\mathrm{g})+\mathrm{H}_{2} \mathrm{O}=\mathrm{ZnO}(\mathrm{s})+\mathrm{H}_{2}(\mathrm{~g})$

Moreover, $\mathrm{ZnO}$ can react with $\mathrm{H}_{2} \mathrm{~S}$ to form zinc sulphide (reaction 3).

$\mathrm{ZnO}(\mathrm{s})+\mathrm{H}_{2} \mathrm{~S}(\mathrm{~g})=\mathrm{ZnS}(\mathrm{g})+\mathrm{H}_{2} \mathrm{O}(\mathrm{g})$

Therefore, the explanation for the lower recovery of $\mathrm{Zn}$ in bottom ash in reducing conditions is the higher volatility of $\mathrm{Zn}$ in the flow gas in $\mathrm{ZnO}$ and $\mathrm{ZnS}$ forms which are captured in the fly ash (Fig. 7e).

\section{Conclusions}

Experimental investigation and thermodynamic equilibrium calculations were carried out to identify the transformation and the possible reactions of HMs during the thermal disposal of a $\mathrm{Zn}$ and Cd hyperaccumulator $-S$. plumbizincicola biomass.

It is optimal to maintain the temperature above $700{ }^{\circ} \mathrm{C}$ with excess air supply in the thermal disposal of $\mathrm{S}$. plumbizincicola. Most $\mathrm{Cl}, \mathrm{S}, \mathrm{Fe}$, $\mathrm{Al}$, and $\mathrm{SiO}_{2}$ were found as $\mathrm{CaCl}_{2}, \mathrm{KCl}, \mathrm{SO}_{2}, \mathrm{Fe}_{2}\left(\mathrm{SO}_{4}\right)_{3}, \mathrm{Fe}_{2} \mathrm{O}_{3}, \mathrm{FeO}$, $\mathrm{Ca}_{3} \mathrm{Al}_{2} \mathrm{O}_{6}, \mathrm{~K}_{2} \mathrm{SiO}_{3}$, and $\mathrm{SiO}_{2}$ during the combustion process instead of reacting with $\mathrm{HMs}$.

The likeliest chemical forms of $\mathrm{Pb}$ in combustion conditions are the pure metal and its oxide in both fly ash and bottom ash. For $\mathrm{Cd}$ and $\mathrm{Zn}$, possible components are the pure metals, their oxides and carbonates, and silicate compounds may be found under low temperature conditions. Under reducing conditions, $\mathrm{Pb}$ and $\mathrm{Cd}$ form heavy metal complex compounds such as $\mathrm{Ca}_{0.75} \mathrm{Cd}_{0.25} \mathrm{O}, \mathrm{Pb}_{2} \mathrm{O}_{3.333}$ or complex compounds with other metals $(\mathrm{Cu}, \mathrm{Al}$, and $\mathrm{Ag}$ ) while $\mathrm{Zn}$ can be pure metal, crystalline oxide, sulphide or complex compounds with other metals.

Most of the original mass of S. plumbizincicola was reduced. Fly ash and/or bottom ash fractions were given high enrichment (>99\%) in $\mathrm{Cd}, \mathrm{Pb}$, and $\mathrm{Zn}$ after the thermal disposal. Thermal disposal of $S$. plumbizincicola might allow the achievement of a sustainable and environmentally safe production of energy from HM-polluted land.

\section{Acknowledgements}

We thank the National Natural Science Foundation of China (41325003, U1361115 and 51276040) and the National High Technology
Research and Development (863) Program of China (2012AA101402-2) for financial support.

\section{References}

[1] M.M. Lasat, Phytoextraction of toxic metals: a review of biological mechanisms, Journal of Environmental Quality 31 (2002) 109-120.

[2] J. Jiang, L. Wu, N. Li, Y. Luo, L. Liu, Q. Zhao, L. Zhang, P. Christie, Effects of multiple heavy metal contamination and repeated phytoextraction by S. plumbizincicola on soil microbial properties, European Journal of Soil Biology 46 (2010) 18-26.

[3] L.H. Wu, YJ. Liu, YJ. Liu, S.B. Zhou, F.G. Guo, D. Bi, X.H. Guo, AJ.M. Baker, A.J.M. Baker, J.A.C. Smith, Y.M. Luo, S. plumbizincicola, X.H. Guoet, S.B. Zhou ex, L.H. Wu, (Crassulaceae): a new species from Zhejiang Province, China, Plant Systematics and Evolution 299 (2013) 487-498.

[4] J. Jiang, L. Wu, N. Li, Y. Luo, L. Liu, Q. Zhao, L. Zhang, P. Christie, Effects of multiple heavy metal contamination and repeated phytoextraction by S. plumbizincicola on soil microbial properties, European Journal of Soil Biology 46 (2010) 18-26.

[5] A. Sas-Nowosielska, R. Kucharski, E. Małkowski, M. Pogrzeba, J.M. Kuperberg, K. Kryński, Phytoextraction crop disposal - an unsolved problem, Environmental Pollution 128 (2004) 373-379.

[6] European Commission, Integrated Pollution Prevention and Control, Reference Document on the Best Available Techniques for Waste Incineration, Aug. 2006.

[7] A. Jakob, S. Stucki, R.P.W.J. Struis, Complete heavy metal removal from fly ash by heat treatment: influence of chlorides an evaporation rates, Environmental Science \& Technology 30 (1996) 3275-3283.

[8] O. Knacke, O. Kubaschewski, K. Hesselmann, Thermochemical Properties of Inorganic Substances, Springer-Verlag, Berlin Heidelberg, 1991.

[9] P. Brunner, H. Mönch, The flux of metals through municipal solid waste incinerators, Waste Management \& Research 4 (1986) 105-119.

[10] A. Ljung, A. Nordin, Theoretical feasibility for ecological biomass ash recirculation: chemical equilibrium behavior of nutrient elements and heavy metals during combustion, Environmental Science \& Technology 31 (1997) 499-503.

[11] K. Lundholm, A. Nordin, R. Backman, Trace elements speciation in combustion processes a review and compilations of thermodynamic data, Fuel Processing Technology 88 (2007) 1060-1070.

[12] X.L. Yan, T.B. Chen, X.Y. Liao, Z.C. Huang, J.R. Pan, T.D. Hu, C.J. Nie, H. Xie, Arsenic transformation and volatilization during incineration of the hyperaccumulator Pteris vittata L, Environmental Science \& Technology 42 (2008) 1479-1484.

[13] S. Lu, Y. Du, D. Zhong, B. Zhao, X. Li, M. Xu, Z. Li, Y. Luo, J. Yan, L. Wu, Comparison of trace element emissions from thermal treatments of heavy metal hyperaccumulators, Environmental Science \& Technology (2012) 5025-5031.

[14] T. Lind, T. Valmari, E.I. Kauppinen, G. Sfiris, K. Nilsson, W. Maenhaut, Volatilization of the heavy metals during circulating fluidized bed combustion of forest residue, Environmental Science \& Technology (1999) 496-502.

[15] D. Verhulst, A. Buekens, P. Spencer, G. Eriksson, Thermodynamic behavior of metal chlorides and sulfates under the conditions of incineration furnaces, Environmental Science \& Technology 30 (1996) 50-56.

[16] K. Wang, K. Chiang, S. Lin, Tsai, C. Sun, Effects of chlorides on emissions of toxic compounds in waste incineration: study on partitioning characteristics of heavy metal, Chemosphere 38 (1999) 1833-1849.

[17] L. Wu, D. Zhong, Y. Du, S. Lu, D. Fu, Z. Li, X. Li, Y. Chi, Y. Luo, J. Yan, Emission and control characteristics for incineration of S. plumbizincicola biomass in a laboratoryscale entrained flow tube furnace, International Journal of Phytoremediation 15 (2013) 219-231.

[18] L.L. Li, G. Wang, S.Y. Wang, S. Qin, Thermogravimetric and kinetic analysis of energy crop Jerusalem artichoke using the distributed activation energy model, Journal of Thermal Analysis and Calorimetry 114 (2013) 1183-1189.

[19] D.K. Shen, S. Gu, K.H. Luo, A.V. Bridgwater, M.X. Fang, Kinetic study on thermal decomposition of woods in oxidative environment, Fuel 88 (2009) 1024-1030.

[20] J.M. Cai, L.S. Bi, Kinetic analysis of wheat straw pyrolysis using isoconversional methods, Journal of Thermal Analysis and Calorimetry 98 (2009) 325-330.

[21] A. Aboulkas, K. El Harfi, M. Nadifiyine, A. El Bouadili, Thermogravimetric characteristics and kinetic of co-pyrolysis of olive residue with high density polyethylene, Journal of Thermal Analysis and Calorimetry 91 (2008) 737-743.

[22] J. Liu, Q. Falcoz, D. Gauthier, G. Flamant, C. Zheng, Volatilization behavior of Cd and $\mathrm{Zn}$ based on continuous emission measurement of flue gas from laboratory-scale coal combustion, Chemosphere 80 (2010) 241-247.

[23] L. Sun, S. Abanades, J.D. Lu, G. Flamant, D. Gauthier, Volatilization of heavy metals during incineration of municipal solid wastes, Journal of Environmental Sciences 16 (2004) 635-639.

[24] J.R. Bunt, F.B. Waanders, Trace element behaviour in the Sasol-Lurgi MK IV FBDB gasifier, Part 1 - the volatile elements - Hg, As, Se, Cd and PbFuel 87 (2008) 2374-2387.

[25] F. Frandsen, K. Dam-Johansen, Rasmussen, Progress in Energy and Combustion Science, 201994. 115-138.

[26] Y. Zhang, Y. Chen, A. Meng, Q. Li, H. Cheng, Experimental and thermodynamic investigation on transfer of cadmium influenced by sulfur and chlorine during municipal solid waste (MSW) incineration, Journal of Hazardous Materials 153 (2008) 309-319.

[27] H. Vogg, Behavior of metals in the incineration of municipal wastes, International Chemical Engineering 27 (1987) 177-182.

[28] A.L. Elled, L.E. Amand, D. Eskilsson, Fate of Zinc during combustion of demolition wood in a fluidized bed boiler, Energy and Fuels 22 (2008) 1519-1526.

[29] R. Backman, M. Hiltunen, M. Hupa, K. Peltola, R. Backman, M. Hiltunen, M. Hupa, K. Peltola, Interaction of the behavior of lead and zinc with alkalis in fluidized bed 
combustion or gasification of waste derived fuels, In Proceedings of 18th International Conference on Fluidized Bed Combustion, 25, May 222005 Toronto, Canada.

[30] S. Abanades, G. Flamant, B. Gagnepain, D. Gauthier, Fate of heavy metals during municipal solid waste incineration, Waste Management \& Research 20 (2002) 55-68.

[31] D. Verhulst, A. Buekens, P.J. Spencer, G. Eriksson, Thermodynamic behavior of metal chlorides and sulfates under the conditions of incineration furnaces, Environmental Science \& Technology 30 (1996) 50-56.

[32] A. Jakob, S. Stucki, P. Kuhn, Evaporation of heavy metals during the heat treatment of municipal solid waste incinerator fly ash, Environmental Science \& Technology 29 (9) (1995) 2429-2436.

[33] P. Chun, M.J. Hall, Sorbent capture of lead and barium in a bench-scale incinerator combusting simulated waste lubricating oil, Combustion Science and Technology 116 (1996) 517-539.
34] A.D. Tillman, A.J. Rossi, K.M. Vick, Incineration of Municipal and Hazardous Solid Wastes. In Mass Burn Systems for Combustion of Municipal Solid Waste, Academic Press, San Diego, CA, 1989.

[35] H. Belevi, M. Langmeier, Factors determining the element behavior in municipal solid waste incinerators. 2. Laboratory experiments, Environmental Science \& Technology 34 (2000) 2507-2512.

[36] A. Cox, D.J.T.I. Fray, Min, Zinc reoxidation in the shaft of a zinc-lead imperial smelting furnace - 1: zinc-carbon-oxygen system with deposition initiated on a quartz substrate and subsequent propagation on zinc oxide, Transactions of the Institution of Mining and Metallurgy Section C-Mineral Processing and Extractive Metallurgy, C. 1092000. C97-C104.

[37] J.M. Osborne, W.J. Rankin, D.J. McCarthy, D.R. Swinbourne, The oxidation of zinc vapor in $\mathrm{CO}-\mathrm{CO}_{2}-\mathrm{N}_{2}$ gas mixtures, Metallurgical and Materials Transactions B 32B (2001) 37-45. 